\title{
Regulation of Renin Release via Cyclic ADP-Ribose-Mediated Signaling: Evidence from Mice Lacking CD38 Gene
}

\author{
Jing Xiong Min Xia Fan Yi Justine M. Abais Ningjun Li Krishna M. Boini Pin-Lan Li
}

Department of Pharmacology \& Toxicology, Medical College of Virginia Campus, Virginia

Commonwealth University, Richmond, VA

\section{Key Words}

ADP-ribosylcyclase $\cdot \mathrm{Ca}^{2+}$ signaling - Renin angiotensin II system • Renal hemodynamics • Juxtaglomerular apparatus

\begin{abstract}
Background/Aims: Despite extensive studies, the intracellular regulatory mechanism of renin production and release is still poorly understood. The present study was designed to test whether CD38-ADP-ribosylcyclase signaling pathway contributes to the regulation of renin production and release, and to examine whether CD38 gene knockout $\left(\mathrm{CD}^{-8^{--}}\right)$can change this important renal endocrinal function. Methods: ADP-ribosylcyclase activity was estimated utilizing HPLC, CADPR levels from western blot, plasma renin activity from RIA kit, urinary sodium and potassium excretion from flame photometry. Results: The expression of CD38 and the activity of ADP-ribosylcyclase to produce cyclic ADP-ribose (CADPR) were nearly abolished in the kidney from $\mathrm{CD}^{--}$mice, indicating that $\mathrm{CD} 38$ gene is a major enzyme responsible for the generation of CADPR in vivo. Mice lacking CD38 gene showed increased plasma renin activity (PRA) in either conscious or anesthetized status $(P<0.05)$. Low salt intake significantly increased, but high salt intake significantly decreased renin release in both $\mathrm{CD} 8^{+/+}$and CD38 $1-$ mice. In acute experiments, it was demonstrated that plasma renin activity (PRA) significantly increased upon isoprenaline infusion in $\mathrm{CD} 38^{\%}$ mice compared to $\mathrm{CD} 38^{+/+}$ mice. Accompanied with such increase in PRA, glomerular filtration rate (GFR), renal blood flow (RBF), urine volume (UV) and sodium excretion $\left(\mathrm{U}_{\mathrm{Na}} \mathrm{V}\right)$ more significantly decreased in $\mathrm{CD}^{-1 /}$ than $\mathrm{CD}^{+/+}$mice. Similarly, more increases in PRA but more decreases in GFR, RBF, $\mathrm{UV}$ and $\mathrm{U}_{\mathrm{Na}} \mathrm{V}$ were observed in $\mathrm{CD} 38^{-/}$than $\mathrm{CD} 38^{+/+}$mice when they had a low renal perfusion pressure (RPP). Conclusion: CD38-CADPR-mediated signaling may importantly contribute to the maintenance of low PRA and participate in the regulation of renal hemodynamics and excretory function in mice.
\end{abstract}


Xiong/Xia/Yi et al.: Renin Release in CD38 Gene Knockout Mice

\section{Introduction}

Cyclic ADP-ribose (cADPR), as a second messenger, has been shown to play an important role in the regulation of intracellular calcium level $\left(\left[\mathrm{Ca}^{2+}\right]_{\mathrm{i}}\right)$ of a variety of cells. This endogenous metabolite of nicotinamide adenine dinucleotide (NAD) via ADP-ribosylcyclase releases $\mathrm{Ca}^{2+}$ from the sarcoplasmic reticulum (SR) via ryanodine receptors (RyRs), which are completely independent of the $\mathrm{IP}_{3}$ signaling pathway [1-3]. It has been reported that the homologues of ADP-ribosylcyclase in mammalian cell are mainly CD38 and CD157 (BST-1) [4-5]. The CD38cADPR-mediated $\mathrm{Ca}^{2+}$ signaling has been so far known as an important signaling pathway in the regulation of a variety of cell functions or physiological processes such as insulin release, egg fertilization, cell proliferation, muscle contraction, neurotransmitter release and nitric oxide production $[3,6]$. Recent studies have demonstrated that cADPR-mediated $\mathrm{Ca}^{2+}$ signaling also plays an important role in the regulation of renal function by its actions on the renal vasculature, glomeruli and nephrons [7-11].

The renin-angiotensin II system (RAS) is a major regulatory system of cardiovascular and renal function [12]. In this hormonal cascade system, the rate-limiting enzyme, renin is primarily synthesized and secreted into circulation by renal juxtaglomerular (JG) cells, one of the JG apparatus components [13]. Renin release is controlled by cyclic adenosine monophosphate (cAMP) and by calcium signaling pathways [14]. In contrast to most of other secretory cells where $\mathrm{Ca}^{2+}$ initiates, supports or maintains exocytosis, renin production and release from JG cells are inhibited by increased $\left[\mathrm{Ca}^{2+}\right]_{\mathrm{i}}[15,16]$. Recently, we have demonstrated that cADPR-mediated $\mathrm{Ca}^{2+}$ signaling pathway is importantly involved in the regulation of renin production and release in As4.1 cells, a prototype of renal JG cells [17]. However, it remains unknown whether this $\mathrm{Ca}^{2+}$ signaling pathway participates in the control of renin release in vivo in response to a variety of physiological and/or pathological stimuli and whether such a mechanism of renin release is involved in the regulation of renal functions. The present study utilized CD38 gene knockout mice to address this important issue. We first compared the difference in plasma renin activity (PRA) between CD38\% mice and their wild type controls. We then detected the renin release in response to different acute and chronic stimulations and finally determined its effects on renal hemodynamics and excretory functions. Our results demonstrated that CD38-cADPR signaling is an important pathway in the regulation of renin release and renal function.

\section{Materials and Methods}

\section{Animals}

Male CD38 gene knockout mice (CD38\%) and wild-type mice (CD38 ${ }^{+/+}$) on the C57BL/6 genetic background (Jackson Laboratory, Bar Harbor, Maine) were used for this study. All animal protocols were approved by the Animal Care Committee of the Virginia Commonwealth University. Animals were fed either a low-salt $(0.04 \% \mathrm{NaCl})$, normal-salt $(0.3 \% \mathrm{NaCl})$, or high-salt $(4.0 \% \mathrm{NaCl})$ diet for 2 weeks as indicated in specific protocols for different experimental purposes. Tap water was provided ad libitum.

\section{Genotyping}

Each mouse was genotyped for CD38 gene using a validated PCR protocol provided by the Jackson Laboratory. Briefly, genomic DNA from the tail was subjected to PCR amplification using taq DNA polymerase (Invitrogen, Inc., Grand Island, NY). PCR was performed by denaturing the DNA at $94^{\circ} \mathrm{C}$ for $5 \mathrm{~min}$, followed by 35 cycles of amplification: $94^{\circ} \mathrm{C}$ for $1 \mathrm{~min}, 57^{\circ} \mathrm{C}$ for $1 \mathrm{~min}, 72^{\circ} \mathrm{C}$ for $1.5 \mathrm{~min}$, and a final extension step at $72^{\circ} \mathrm{C}$ for $10 \mathrm{~min}$. The following CD38-specific primers including oIMR0092 (5'-AAT CCA TCT TGT TCA ATG GCC GAT C-3'), oIMR7727 (5'-CAC CAT AAG AGG GGA AGC AA-3'), and oIMR7728 (5'-TGC CAA AAG TGC AGA AGA GA-3') was provided by the Jackson Laboratory and used for genotyping. The PCR products were separated in 1.5\% agarose gel electrophoresis and visualized by ethidium bromide fluorescence with 100 pb DNA ladder as marker (MBI Fermentas, Inc., Amherst, NY). 
Xiong/Xia/Yi et al.: Renin Release in CD38 Gene Knockout Mice

\section{Western blot analysis}

Tissue homogenates from the renal cortex were prepared as we described previously [18]. CD38 protein was detected by Western blot analysis with a monoclonal antibody against CD38 (BD Biosciences, San Diego, $\mathrm{CA}$ ). The antibody was 1:1000 diluted and incubated with the membrane overnight at $4^{\circ} \mathrm{C}$. Western blot was also performed with rabbit polyclonal antibody against renin (1:1000 dilution; Abcam, Cambridge, MA). For normalization, the membranes were re-probed with antibody against the housekeeping protein $\beta$-actin (1:5000; Santa Cruz Biotechnology, Inc., Santa Cruz, California) for $1 \mathrm{~h}$ incubation at room temperature. The films with immunoreactive blots were scanned, and the intensity of protein bands was quantitated using a computer program of UN-SCAN-IT gel (Silk Scientific Inc., Orem, Utah).

\section{HPLC for analysis of ADP-ribosylcyclase activity in the kidney}

To determine ADP-ribosylcyclase activity, the homogenate, cytosol or microsomes (100 $\mu$ g protein) from the kidney was incubated with $\beta$-nicotinamide guanine dinucleotide $\left(\beta-\mathrm{NGD}^{+}, 100 \mu \mathrm{M}\right)$ at $37^{\circ} \mathrm{C}$ for 20 minutes. $\beta-\mathrm{NGD}^{+}$was used as a substrate to determine ADP-ribosylcyclase activity, because this enzyme converts NGD into cyclic GDP-ribose (CGDPR); but unlike cADPR, cGDPR cannot be hydrolyzed by cADPR hydrolase, which increased the sensitivity for measurement of ADP-ribosylcyclase activity. The reaction mixtures were centrifuged at $4^{\circ} \mathrm{C}$ for $10 \mathrm{~min}$ at $13,800 \mathrm{~g}$ to remove proteins, and then analyzed by HPLC with a fluorescence detector (Hewlett-Packard 1090 HPLC system and 1046A spectrofluorometer). The excitation wavelength of $300 \mathrm{~nm}$ and the emission wavelength of $410 \mathrm{~nm}$ were used to detect the fluorescent products. All HPLC data were collected and analyzed by a Hewlett-Packard Chemstation. The detailed procedures were described previously [17].

\section{Cycling assay of cADPR levels in the kidney}

The cADPR basal levels in the kidney from WT and CD38 $\%$ mice were determined as described previously $[17,18]$. Tissue samples were homogenized and extracted with $0.5 \mathrm{ml}$ of $0.6 \mathrm{M}$ perchloric acid at $4^{\circ} \mathrm{C}$. Perchloric acid was removed by mixing the aqueous sample with a solution containing 3:1 volume of 1, 1,2- trichlorotrifluoroethane to tri- $n$-octylamine. Following centrifugation for 10 minutes at $1,500 \mathrm{~g}$, the aqueous layer containing cADPR was removed and incubated overnight at $37^{\circ} \mathrm{C}$ with an enzyme mixture containing: $0.44 \mathrm{unit} / \mathrm{ml}$ nucleotide pyrophosphatase, $12.5 \mathrm{units} / \mathrm{ml}$ alkaline phosphatase, $0.0625 \mathrm{unit} / \mathrm{ml}$ NADase, $2.5 \mathrm{mM} \mathrm{MgCl}_{2}$ and $20 \mathrm{mM}$ sodium phosphate (pH 8.0). In this way, all nucleotides except cADPR in the samples were hydrolysed. To quantify cADPR concentration, a cycling reaction was conducted in 96well plates. First, $0.1 \mathrm{ml}$ of cADPR or other nucleotide samples were added into $50 \mu \mathrm{l}$ of reagent containing $0.3 \mu \mathrm{g} / \mathrm{ml}$ ADP-ribosylcyclase, $30 \mathrm{mM}$ nicotinamide and $100 \mathrm{mM}$ sodium phosphate (pH 8.0). This initiated the conversion of cADPR in the samples into NAD+. The conversion was allowed to proceed for 15 minutes at room temperature. The cycling reagent $(0.1 \mathrm{ml})$ was then added, which contained $2 \%$ ethanol, $100 \mu \mathrm{g} /$ $\mathrm{ml}$ alcohol dehydrogenase, $20 \mu \mathrm{M}$ resazurin, $10 \mu \mathrm{g} / \mathrm{ml}$ diaphorase, $10 \mu \mathrm{M}$ FMN, $10 \mathrm{mM}$ nicotinamide, 0.1 $\mathrm{mg} / \mathrm{ml} \mathrm{BSA}$ and $100 \mathrm{mM}$ sodium phosphate ( $\mathrm{pH} \mathrm{8.0)}$. The cycling reaction was allowed to proceed for 2-4 hours, and increase in the resorufin fluorescence (with excitation at $544 \mathrm{~nm}$ and emission at $590 \mathrm{~nm}$ ) was measured periodically using a fluorescence plate reader. With known concentrations of standard curve, quantitative measurements were performed.

\section{RNA extraction and real time RT-PCR}

Total RNA was isolated from kidney tissues using TRIzol reagent (GIBCO, Grand Island, NY) according to the protocol described by the manufacturer. The mRNA levels for renin were analyzed by real-time RT-PCR using a Bio-Rad iCycler system (Bio-Rad, Hercules, CA) according to the protocol described by the manufacturer. The mRNA level of renin was normalized to $\beta$-actin RNA. The primers used in this study were synthesized by Operon (Huntsville, AL, USA) and the sequences were: renin sense GGGAGCCAAGGAGAAGAGA, antisense TCCCAGGTCAAAGGAAATGT; $\beta$-actin sense TCGCTGCGCTGGTCGTC, antisense GGCCTCGTCACCCACATAGGA.

\section{Double-Immunofluorescent Staining}

Double-immunofluorescent staining was performed using frozen slides from mouse kidneys. After fixation with acetone, the slides were incubated overnight at $4^{\circ} \mathrm{C}$ with rat anti-renin antibody and sheep anti-CD38 antibody (R\&D, Minneapolis, MN), which was followed by incubation with Alexa555-labeled goat 
Xiong/Xia/Yi et al.: Renin Release in CD38 Gene Knockout Mice

anti-rat and Alexa488-labeled donkey anti-sheep secondary antibodies for 1 hour at room temperature. Finally, the slides were mounted and subjected to examination for colocalization of renin and CD38 in JG apparatus or glomerular afferent arterioles using a confocal laser scanning microscope (Fluoview 1000, Olympus).

Plasma renin activity (PRA) measurement

PRA was determined by generation of angiotensin I from a plasma angiotensinogen substrate by RIA kit (DiaSorin, Stillwater, MN) according to the protocol described by the manufacturer [19].

\section{Acute animal experiments}

Male $\mathrm{CD} 8^{+/+}$and CD38\% mice weighing 20 30 g were used for these experiments. The surgery was performed as described previously [20,21]. In brief, after being fasted overnight the mice were anesthetized with ketamine (50 $\mu \mathrm{g} / \mathrm{g}$ intraperioneally; Parke-Davis GmbH, Berlin, Germany) and inactin (100 $\mu \mathrm{g} / \mathrm{g}$ intraperitoneally; Res Biochemical, Inc., Natick, MA) and then placed on a heated table for maintenance of body temperature at $37^{\circ} \mathrm{C}$. A cannula (PE 90) were placed into the trachea for facilitating breathing, and other cannulae (PE 10) were placed into the left femoral vein for infusion of $2 \%$ albumin saline (at $2 \mu \mathrm{l} /$ $\mathrm{min} / \mathrm{g}$ body weight), into the left femoral artery for measurement of renal perfusion pressure (RPP), and into the urinary bladder (PE 50) for urine collection, respectively. After a midline and then flank incision, a $0.5 \mathrm{~mm}$ V-series flow probe (Transonic System, Inc., Ithaca, NY) was placed around the left renal artery and connected to a flowmeter (T206; Transonic System, Inc., Ithaca, NY) to measure renal blood flow (RBF). After completion of surgery, the albumin saline infusion was changed to an albumin saline containing inulin $(15 \mathrm{mg} / \mathrm{ml})$ throughout the experiment. Animal experiments protocols were as follows:

\section{Protocol 1: Isoprenaline infusion}

Isoprenaline infusion has been often used to stimulate renin release acutely [20]. To perform these experiments, mice were divided into 4 groups ( $\mathrm{n}=8$ in each group) including $\mathrm{CD} 38^{+/+}$mice with or without i.v. infusion of isoprenaline and $\mathrm{CD}_{3} 8^{-/}$mice with or without isoprenaline infusion. After a 2-h equilibration period, urine was collected over two 30 minute periods as control. Isoprenaline (Sigma, St. Louis, MO) was then infused i.v. at $800 \mathrm{ng} / \mathrm{kg} / \mathrm{min}$ and urine continuously collected for six 30-minute periods. At the end of the experiments, approximately $0.3 \mathrm{ml}$ arterial blood samples were taken through the catheter in the femoral artery using a cooled syringe containing EDTA. To minimize the impact of blood sampling on renin secretion, the blood was drawn within the shortest time ( $\sim 35$ seconds) without renin elevation (data not shown). The plasma was aliquoted and frozen for late estimation of PRA, plasma inulin concentrations and others.

After the above protocols, the RBF, glomerular filtration rate (GFR), urine volume (UV), absolute $\mathrm{Na}^{+}$ excretion $\left(\mathrm{U}_{\mathrm{Na}} \mathrm{V}\right)$, fractional $\mathrm{Na}^{+}$excretion $\left(\mathrm{FE}_{\mathrm{Na}}\right)$, absolute $\mathrm{K}^{+}$excretion $\left(\mathrm{U}_{\mathrm{k}} \mathrm{V}\right)$ and fractional $\mathrm{K}^{+}$excretion $\left(\mathrm{FE}_{\mathrm{k}}\right)$ were measured or calculated.

\section{Protocol 2: RPP reduction}

Reduction of RPP is another classical stimulus for renin production and release [21]. In this experiment, mice were also divided into 4 groups ( $\mathrm{n}=8$ in each group) including $\mathrm{CD}_{38^{+/+}}$mice with or without RPP reduction and CD38\% with or without RPP reduction. The abdominal aorta above the kidney was isolated for late occlusion by an adjustable clamp so that the RPP could be reduced to the desired value. After a 2-h equilibration period, urine was collected over two 30 minute control periods and then RPP was gradually reduced to $60 \mathrm{mmHg}$, and urine continuously collected for six 30-minute periods when the RPP was maintained at $60 \mathrm{mmHg}$. At the end of the experiments, approximately $0.3 \mathrm{ml}$ arterial blood samples were taken and plasma prepared for analysis of PRA, inulin concentrations and others as described above.

\section{Statistical Analysis}

Data were provided as arithmetic means $\pm \mathrm{SEM} ; n$ represents the number of independent animal experiments. All data were tested for significance using ANOVA or paired and unpaired Student's t-test as applicable. Only results with $\mathrm{p}<0.05$ were considered statistically significant. 


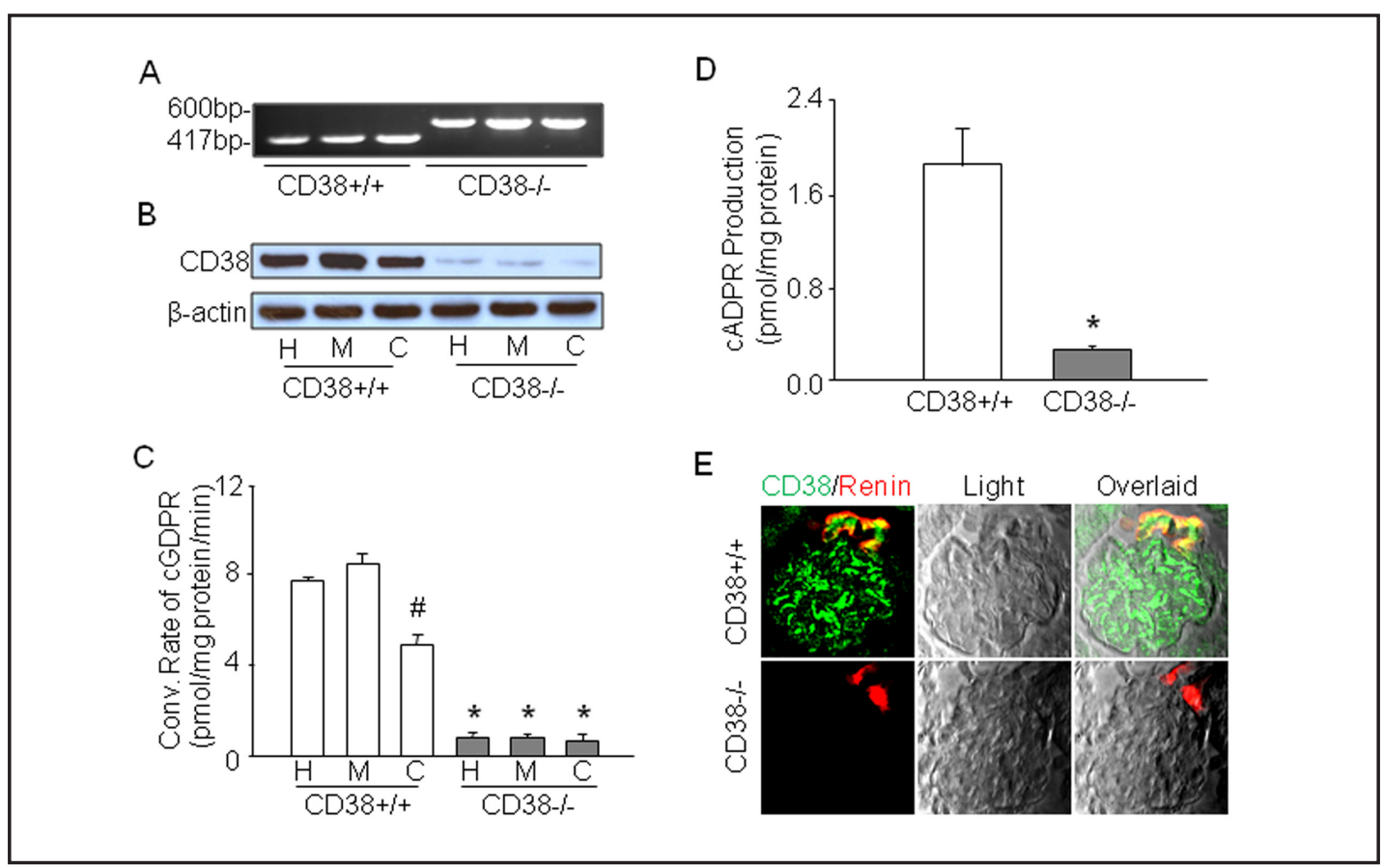

Fig. 1. CD38 expression and ADP-ribosylcyclase activity in the kidneys from $\mathrm{CD}_{3} 8^{+/+}$and $\mathrm{CD} 38^{-/}$mice. A: Confirmation of CD38\% mice by genotyping. CD38 gene-specific PCR product (417 bp) was amplified from WT mice (lane 1, 2, 3), but not from CD38\% mice (lane 4, 5, 6). B: CD38 protein expression in the homogenate, cytosol and microsome of the kidneys from $\mathrm{CD}_{3}{ }^{+/+}$and $\mathrm{CD} 38^{-/-}$mice by Western blot. C: ADP ribosylcyclase activity in the homogenate, cytosol and microsome of the kidneys from $\mathrm{CD}^{+/ /+}$and $\mathrm{CD} 38^{-/}$mice by HPLC. Summarized data showed the conversation rate of $\beta-\mathrm{NAD}^{+}$into $\mathrm{CGDPR}$, which indicates the activity of ADPribosylcyclase. D: Basal values of cADPR in the kidney homogenate from $\mathrm{CD} 38^{+/+}$and $\mathrm{CD} 38^{\% /-}$ mice by cycling assay. E: The expression of CD38 in JG apparatus and afferent arterioles around glomerulus was detected by colocalization of CD38 and renin by immunofluorescent confocal microscopy. ${ }^{*} P<0.05$ vs. $\mathrm{CD}^{2} 8^{+/+}$mice; ${ }^{\#} P<0.05$ vs. microsomes in $\mathrm{CD}^{2} 8^{+/+}$mice $(\mathrm{n}=8)$.

\section{Results}

CD38 expression and ADP-ribosylcyclase activity in the kidneys from $\mathrm{CD}^{2} 8^{+/+}$and CD38\% mice

Genotyping of CD38\% mice was performed by PCR of tail DNA for each batch of mice. As shown in Fig. 1A, CD38 gene-specific PCR product was detected from WT mice, but not from $\mathrm{CD} 38 \%$ mice. CD38 proteins were hardly detected in the kidneys from CD38\% mice, while it was enriched in the kidneys from $\mathrm{CD} 38^{+/+}$mice (Fig. 1B). Accordingly, the ADPribosylcyclase activities were nearly undetectable in the kidneys from CD38\% mice (Fig. 1C). The enzymatic activities were much higher in microsomes than cytosol fraction from the kidneys of $\mathrm{CD}^{+/++}$mice (Fig. 1C). Similarly, the basal levels of cADPR in the kidneys from $\mathrm{CD}^{+/+}$mice were about 7 times higher than that from $\mathrm{CD}^{\circ} \%$ mice $(1.86 \pm 0.32 \mathrm{pmol} / \mathrm{mg}$ vs. $0.27 \pm 0.03 \mathrm{pmol} / \mathrm{mg}$ ) (Fig. 1D). All these data confirmed that cADPR production in the kidney is critically dependent on the presence of CD38 gene.

To confirm the expression and knocking out of CD38 gene in JG apparatus or afferent arterioles of mice, double-immunofluorescent staining of CD38 and renin was performed in kidney slices and confocal microscopy was conducted to detect colocalization of both protein in JG cells or renin producing cells. As shown in Fig. 1E, CD38 was found ubiquitously distributed in renal cells, including JG cells in CD38 $8^{+/+}$mice. A nice colocalization of CD38 and renin was shown in the area of JG apparatus or afferent arterioles proximal to glomerulus. These results confirmed the presence of CD38 in JG cells, which was consistent with our 


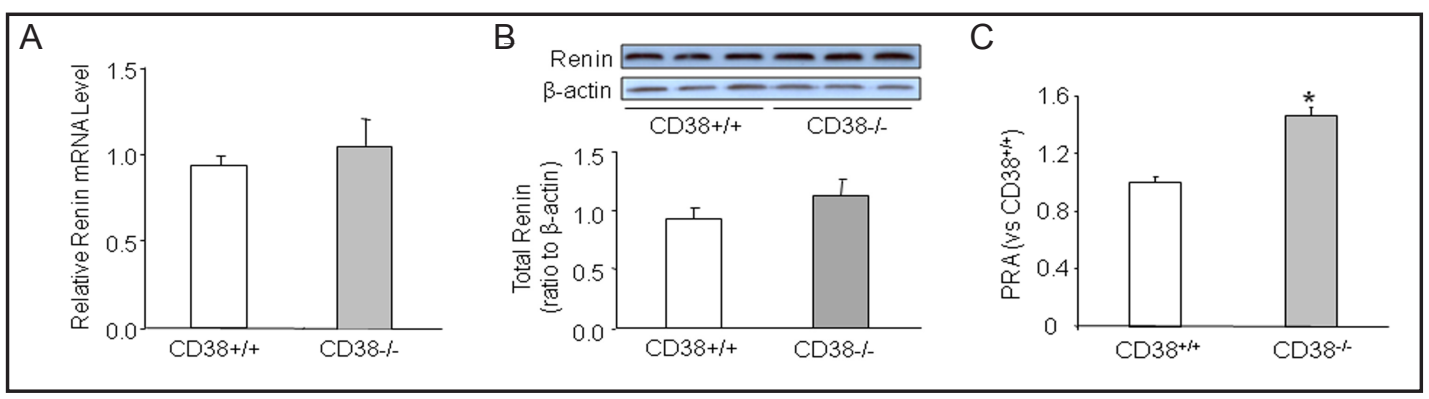

Fig. 2. Detection of renin production and release from $\mathrm{CD} 38^{+/+}$and $\mathrm{CD} 38^{-/-}$mice. A: Renin mRNA expression in the kidneys from $\mathrm{CD}_{3}{ }^{+/+}$and $\mathrm{CD} 38^{-/}$mice. B: Immunoblot gel document of renin in kidney homogenate from $\mathrm{CD}_{3} 8^{+/+}$and $\mathrm{CD} 38^{-/-}$mice. C: Plasma renin activity in $\mathrm{CD}^{+/+}$and $\mathrm{CD}^{-/ /}$mice. ${ }^{*} P<0.05$ vs. $\mathrm{CD}^{2} 8^{+/+}$mice $(n=8)$.

Fig. 3. Effects of different salt intakes on renin secretion in $\mathrm{CD}_{3} 8^{+/+}$and $\mathrm{CD} 38 \%$ mice. Plasma renin activity in $\mathrm{CD}_{3} 8^{+/+}$and $\mathrm{CD} 38^{\%}$ mice. ND: Normal diet, LS: low salt diet, HS: High salt diet. ${ }^{*} p<0.05$ vs. CD38 ${ }^{+/+}$mice; ${ }^{\#} p<0.05$ vs. normal diet fed mice $(n=8)$.

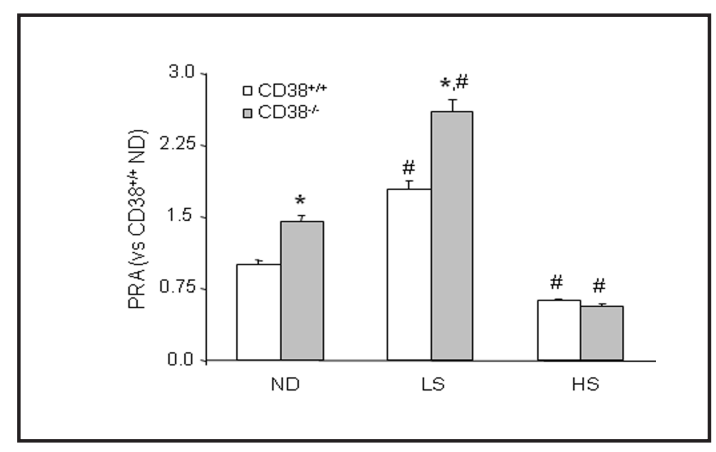

previous report showing that a high CD38 ADP-ribosylcyclase activity was detected in afferent arterioles [22]. However, in CD38 ${ }^{--}$mice, this colocalization disappeared because CD38 was not detectable in the kidney.

Basal renin levels and activities in $\mathrm{CD}^{2} 8^{+/+}$and $\mathrm{CD} 38 \%$ mice

Real time RT-PCR and Western blot analysis showed that there was no significant difference between $\mathrm{CD} 38^{+/+}$and $\mathrm{CD} 38^{-/}$mice in basal renin expression at both mRNA and protein levels (Fig. 2A and 2B). However, it was found that PRA was much higher in CD38\% mice than in $\mathrm{CD}^{+/++}$mice $(13.59 \pm 1.32$ vs. $8.21 \pm 1.08 \mathrm{ng} / \mathrm{ml} / \mathrm{hr}$ ) (Fig. $2 \mathrm{C}$ ).

Effect of salt intake on PRA in $\mathrm{CD} 8^{+/+}$and $\mathrm{CD} 38^{\%}$ mice

As depicted in Figure 3, the plasma renin activity (PRA) was significantly higher in $\mathrm{CD} 8^{-/}$than $\mathrm{CD}^{2} 8^{+/+}$mice on the normal diet. Low salt diet treatment significantly increased the plasma renin activity in both genotypes. Following low salt diet treatment, the PRA was again significantly higher in $\mathrm{CD} 38^{\%}$ mice than in $\mathrm{CD}^{-/ /+}$mice. In contrast, high salt diet treatment significantly decreased the plasma renin activity in both $\mathrm{CD}_{3} \%$ and $\mathrm{CD} 38^{+/+}$mice compared to normal diet fed mice (Fig. 3).

Effect of isoprenaline infusion on RPP and related renal function in $C D 38^{+/+}$and $C D 38^{-\%}$ mice

Isoprenaline is a well-known stimulus of renin release [12]. The isoprenaline infusion decreased RPP and reduced the RBF. The decreases in RPP were sustained in both CD38 $8^{+/+}$ and $\mathrm{CD} 38^{\%}$ mice. Interestingly, the reduction in RBF occurred in the first 30 minutes and then recovered to the baseline level over a 3-h infusion period in $\mathrm{CD}_{3} 8^{+/+}$mice, whereas the reduction in RBF was sustained or further decreased over a 3-h infusion period in CD38\% mice (Fig. 4A and B). Accompanied with this sustained reduction of RBF in CD38 ${ }^{-/-}$mice, the PRA was increased 3.8 fold in response to isoprenaline infusion compared to that in $\mathrm{CD}_{3} 8^{+/+}$ mice (Fig. 4C). 

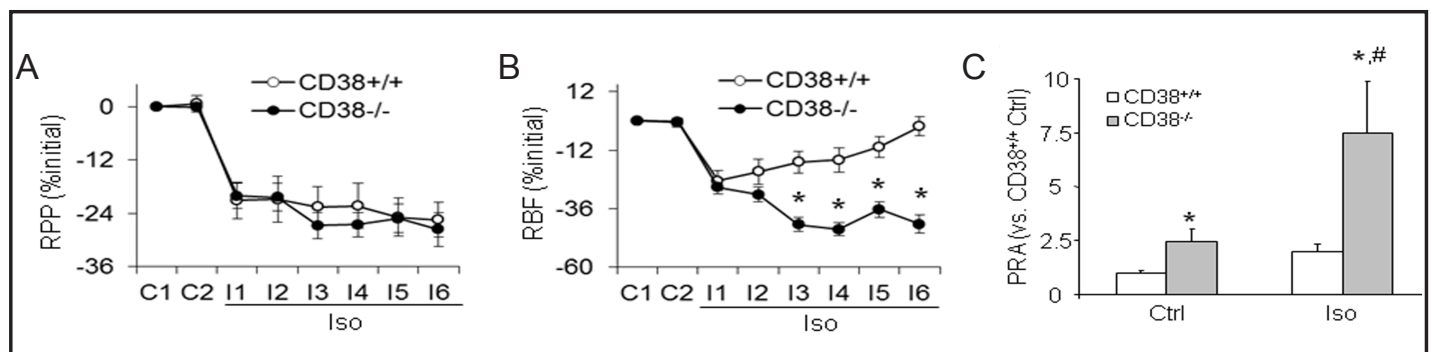

Fig. 4. Effects of isoprenaline on renal perfusion pressure, renal blood flow, and plasma renin concentration in $\mathrm{CD}_{38}^{+/+}$and $\mathrm{CD} 38^{-/}$mice. A: Changes in renal perfusion pressure. B: Changes in renal blood flow. C: Changes in plasma renin activity. Ctrl: Control, Iso: Isoprenaline. ${ }^{*} p<0.05$ vs. CD38 ${ }^{+++}$mice, ${ }^{*} p<0.05$ vs. control mice $(n=8)$.

Table 1. Effect of $3 \mathrm{~h}$ isoprenaline infusion on renal function in $\mathrm{CD}^{2} 8^{+/+}$and $\mathrm{CD} 38^{-/}$mice. Iso: Isoprenaline, h: hour, GFR: glomerular filtration rate, UV: urine volume, $\mathrm{U}_{\mathrm{Na}} \mathrm{V}$ : urinary sodium excretion, $\mathrm{U}_{\mathrm{k}} \mathrm{V}$ : urinary potassium excretion, $\mathrm{FE}_{\mathrm{Na}} \mathrm{V}$ : fractional excretion of sodium, $\mathrm{FE}_{\mathrm{k}} \mathrm{V}$ : fractional excretion of potassium.

\begin{tabular}{|c|c|c|c|c|c|}
\hline & & Basal & Iso $1 \mathrm{~h}$ & Iso $2 \mathrm{~h}$ & Iso $3 \mathrm{~h}$ \\
\hline \multirow{2}{*}{$\begin{array}{c}\text { GFR } \\
(\mathrm{ml} / \mathrm{min} / \mathrm{gkw})\end{array}$} & $\mathrm{CD} 38^{+/+}$ & $0.92 \pm 0.09$ & $0.58 \pm 0.11$ & $0.77 \pm 0.13$ & $0.74 \pm 0.13$ \\
\hline & CD38\% & $0.95 \pm 0.15$ & $0.37 \pm 0.09$ & $0.62 \pm 0.15$ & $0.62 \pm 0.13$ \\
\hline \multirow{2}{*}{$\begin{array}{c}\mathrm{UV} \\
(\mu \mathrm{l} / \mathrm{min} / \mathrm{gkw})\end{array}$} & $\mathrm{CD}_{3} 8^{+/+}$ & $52.23 \pm 6.21$ & $29.22 \pm 8.02$ & $25.32 \pm 7.82$ & $25.81 \pm 4.47$ \\
\hline & CD38 $\%$ & $36.33 \pm 3.50 *$ & $8.46 \pm 2.40^{*}$ & $6.43 \pm 0.93^{*}$ & $7.48 \pm 1.19 *$ \\
\hline \multirow{2}{*}{$\begin{array}{c}\mathrm{U}_{\mathrm{NaV}} \\
(\mu \mathrm{mol} / \mathrm{min} / \mathrm{gkw})\end{array}$} & $\mathrm{CD} 8^{+/+}$ & $13.06 \pm 1.93$ & $5.95 \pm 1.74$ & $4.71 \pm 2.38$ & $3.10 \pm 1.38$ \\
\hline & CD38 $\%$ & $6.99 \pm 0.84^{*}$ & $2.08 \pm 0.53^{*}$ & $0.76 \pm 0.11$ & $1.14 \pm 0.25$ \\
\hline \multirow{2}{*}{$\begin{array}{l}\mathrm{FE}_{\mathrm{Na}} \\
(\%)\end{array}$} & $\mathrm{CD} 8^{+/+}$ & $4.90 \pm 0.31$ & $1.62 \pm 0.31$ & $1.26 \pm 0.32$ & $1.32 \pm 0.45$ \\
\hline & CD38 $\%$ & $3.21 \pm 0.21 *$ & $1.13 \pm 0.35$ & $1.31 \pm 0.80$ & $1.65 \pm 0.97$ \\
\hline \multirow{2}{*}{$\begin{array}{c}\mathrm{U}_{\mathrm{k}} \mathrm{V} \\
(\mu \mathrm{mol} / \mathrm{min} / \mathrm{gkw})\end{array}$} & $\mathrm{CD} 38^{+/+}$ & $3.55 \pm 1.01$ & $1.94 \pm 0.41$ & $1.53 \pm 0.52$ & $1.95 \pm 0.42$ \\
\hline & CD38 $\%$ & $2.22 \pm 0.42$ & $0.99 \pm 0.36$ & $1.35 \pm 0.25$ & $1.85 \pm 0.66$ \\
\hline \multirow{2}{*}{$\begin{array}{l}\mathrm{FE}_{\mathrm{k}} \\
(\%)\end{array}$} & $\mathrm{CD} 8^{+/+}$ & $0.43 \pm 0.06$ & $0.24 \pm 0.04$ & $0.21 \pm 0.06$ & $0.25 \pm 0.05$ \\
\hline & CD38\% & $0.29 \pm 0.03$ & $0.21 \pm 0.03$ & $0.23 \pm 0.05$ & $0.26 \pm 0.06$ \\
\hline
\end{tabular}

The results of renal excretory function obtained from mice receiving isoprenaline infusion were presented in Table 1. GFR decreased after isoprenaline infusion both in $\mathrm{CD}^{+/++}$and CD38\% mice, which was more obvious in CD38\% mice. $\mathrm{UV}, \mathrm{U}_{\mathrm{Na}} \mathrm{V}$ and $\mathrm{FE}_{\mathrm{Na}}$ also significantly decreased in both strains of mice. Compared with $\mathrm{CD}^{+/+}$mice, $\mathrm{CD} 38^{-/-}$mice had lower UV and $\mathrm{U}_{\mathrm{Na}} \mathrm{V}$ at the $1^{\text {st }}$ hour of isoprenaline infusion without significant difference in changes in $\mathrm{FE}_{\mathrm{Na}}$. Moreover, $\mathrm{U}_{\mathrm{k}} \mathrm{V}$ and $\mathrm{FE}_{\mathrm{k}}$ were reduced much less in $\mathrm{CD} 38^{-\%}$ mice than in $\mathrm{CD}^{2} 8^{+/+}$mice.

Changes in PRA and renal function during reduction of $R P P$ in $C D 38^{+/+}$and $C D 38^{-/}$mice

Reducing RPP, another classical method to stimulate renin release, also used to observe the role of CD38-mediated signaling in the regulation of renin release. A marked decrease in $\mathrm{RBF}$ was found in both $\mathrm{CD} 38^{+/+}$and $\mathrm{CD} 38^{-/}$mice. However, RBF was gradually recovered over a 3-h time period in $\mathrm{CD} 38^{+/+}$mice, but not in CD38\% mice (Fig. 5B). Furthermore, the reduction of RPP significantly increased the PRA activitiy (3.8 fold) in CD38 $\%$ than in CD38 $8^{+/+}$ mice (Fig. 5C) . 


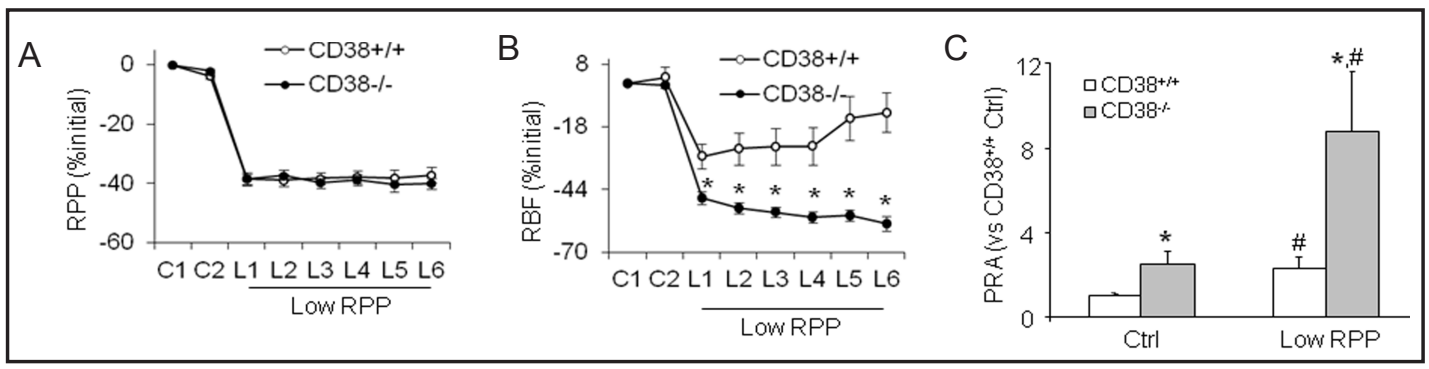

Fig. 5. Effects of low renal perfusion pressure on renal perfusion pressure, renal blood flow and plasma renin concentration in $\mathrm{CD}^{+/ /+}$and $\mathrm{CD} 38^{-/-}$mice. A: Changes in renal perfusion pressure. B: Changes in renal blood flow. C: Changes in plasma renin activity. Ctrl: Control, RPP: Renal perfusion pressure. ${ }^{*} p<0.05$ vs. $\mathrm{CD} 8^{+/+}$mice, ${ }^{*} p<0.05$ vs. control mice $(\mathrm{n}=8)$.

Table 2. Effect of $3 \mathrm{~h}$ RPP reduction on renal function in $\mathrm{CD}_{3} 8^{+/+}$and $\mathrm{CD} 38^{\%}$ mice. RPP: renal perfusion pressure, h: hour; GFR: glomerular filtration rate, $\mathrm{UV}$ : urine volume and $\mathrm{U}_{\mathrm{Na}} \mathrm{V}$ : urinary sodium excretion, $\mathrm{U}_{\mathrm{k}} \mathrm{V}$ : urinary potassium excretion, $\mathrm{FE}_{\mathrm{Na}} \mathrm{V}$ : fractional excretion of sodium, $\mathrm{FE}_{\mathrm{k}} \mathrm{V}$ : fractional excretion of potassium.

\begin{tabular}{|c|c|c|c|c|c|}
\hline & & Basal & Low RPP $1 \mathrm{~h}$ & $\begin{array}{c}\text { Low RPP } \\
2 \mathrm{~h}\end{array}$ & Low RPP 3h \\
\hline \multirow{2}{*}{$\begin{array}{c}\text { GFR } \\
(\mathrm{ml} / \mathrm{min} / \mathrm{gkw})\end{array}$} & CD38+/+ & $1.04 \pm 0.06$ & $0.81 \pm 0.20$ & $0.83 \pm 0.27$ & $0.85 \pm 0.25$ \\
\hline & CD38\% & $0.96 \pm 0.04$ & $0.34 \pm 0.14$ & $0.76 \pm 0.14$ & $0.76 \pm 0.16$ \\
\hline \multirow{2}{*}{$\begin{array}{c}\mathrm{UV} \\
(\mu \mathrm{l} / \mathrm{min} / \mathrm{gkw})\end{array}$} & $\mathrm{CD}_{3} 8^{+/+}$ & $70.04 \pm 6.47$ & $18.01 \pm 3.01$ & $16.70 \pm 3.45$ & $21.93 \pm 3.82$ \\
\hline & CD38 $\%$ & $\begin{array}{l}42.90 \pm \\
5.58^{*}\end{array}$ & $4.87 \pm 0.73^{*}$ & $4.52 \pm 0.73^{*}$ & $5.88 \pm 1.86^{*}$ \\
\hline \multirow{2}{*}{$\begin{array}{c}\mathrm{U}_{\mathrm{NaV}} \\
(\mu \mathrm{mol} / \mathrm{min} / \mathrm{gkw})\end{array}$} & CD38+/+ & $9.19 \pm 1.73$ & $2.36 \pm 0.66$ & $1.91 \pm 0.63$ & $2.95 \pm 1.17$ \\
\hline & CD38 $\%$ & $4.46 \pm 0.66^{*}$ & $0.55 \pm 0.12^{*}$ & $0.54 \pm 0.16$ & $0.54 \pm 0.19$ \\
\hline \multirow{2}{*}{$\begin{array}{l}\text { FENa } \\
(\%)\end{array}$} & CD38+/+ & $3.73 \pm 0.48$ & $1.04 \pm 0.13$ & $0.87 \pm 0.13$ & $1.34 \pm 0.48$ \\
\hline & CD38 $\%$ & $2.22 \pm 0.38 *$ & $0.50 \pm 0.11^{*}$ & $0.35 \pm 0.10^{*}$ & $0.29 \pm 0.09 *$ \\
\hline \multirow{2}{*}{$\begin{array}{c}\mathrm{U}_{\mathrm{k} V} \\
(\mu \mathrm{mol} / \mathrm{min} / \mathrm{gkw})\end{array}$} & CD38+/+ & $4.00 \pm 0.44$ & $1.60 \pm 0.30$ & $1.39 \pm 0.23$ & $1.93 \pm 0.49$ \\
\hline & CD38 $\%$ & $2.13 \pm 0.31^{*}$ & $0.94 \pm 0.39$ & $1.16 \pm 0.32$ & $1.44 \pm 0.32$ \\
\hline \multirow{2}{*}{$\begin{array}{l}\mathrm{FE}_{\mathrm{k}} \\
(\%)\end{array}$} & CD38+/+ & $0.37 \pm 0.05$ & $0.20 \pm 0.03$ & $0.19 \pm 0.03$ & $0.26 \pm 0.09$ \\
\hline & CD38\% & $0.28 \pm 0.05$ & $0.16 \pm 0.03$ & $0.17 \pm 0.03$ & $0.22 \pm 0.03$ \\
\hline
\end{tabular}

The effects of RPP reduction on renal excretory function were presented in Table 2. In CD38 $\%$ mice, GFR decreased more significantly compared with that observed in CD38 $8^{+/+}$ mice $(63.71 \%$ vs. $26.03 \%$, p $<0.05)$. Similarly, $U V$ and $U_{\mathrm{Na}} V$ were reduced much more during decrease in RPP in $\mathrm{CD}_{3}{ }^{-/}$mice than $\mathrm{CD}^{+/+}$mice. $\mathrm{U}_{\mathrm{k}} \mathrm{Va}$ and $\mathrm{FE}_{\mathrm{k}}$ markedly decreased when $\mathrm{RPP}$ fell to $60 \mathrm{mmHg}$, which was much less in $\mathrm{CD}^{-1 /}$ mice than $\mathrm{CD}^{\mathrm{K}} 8^{+/+}$mice.

\section{Discussion}

Using the CD38\% mice with defect of ADP-ribosylcyclase, the present study addressed whether renin production and release are associated with CD38-cADPR signaling pathway in the kidney. It was found that neither basal mRNA nor protein level of renin in the kidney was different between $\mathrm{CD}_{3} \%$ and $\mathrm{CD}^{-/} 8^{+/}$mice, indicating that the deficiency of CD38mediated cADPR production may not be involved in the biogenesis of renin in vivo. However, PRA was significantly increased in $\mathrm{CD}_{3}{ }^{-/}$mice compared to $\mathrm{CD} 38^{+/+}$mice. These results suggest that under normal physiological conditions, CD38-cADPR signaling pathway may 
Xiong/Xia/Yi et al.: Renin Release in CD38 Gene Knockout Mice

mainly contribute to the regulation of renin release but not in renin production. The findings from the present study for the first time reveal the important contribution of this signaling pathway to basal renin release in in vivo animal experiments.

To further clarify the role of CD38 in the regulation of renin release, we performed a series of acute and chronic animal experiments to test whether renin release in response to different stimuli is changed in CD38\% mice. In previous studies, salt intake has been used as a classical chronic physiological means for investigations on renin production and release in the kidney. It is well known that low salt intake increases, while high salt intake decreases renin synthesis and secretion [23]. Our results demonstrated that 2 week low salt intake significantly increased, but high salt intake significantly decreased renin release into plasma in both $\mathrm{CD}_{3}{ }^{+/+}$and $\mathrm{CD} 38^{\%}$ mice. However, high salt-induced decrease in the PRA compared to the level on low salt intake status was more remarkable in $\mathrm{CD} 38^{-/}$mice than $\mathrm{CD}^{2} 8^{+/+}$mice. These results support the view that normal function of CD38-ADP-ribosylcyclase in JG cells as shown by IHC staining may mediate the sensitivity of renin release to salt intake from JG cells. In previous studies, intracellular $\mathrm{Ca}^{2+}$ concentrations of JG cells were shown to be inversely related to the renin production and release [15, 24-26], which may be of importance in salt intake-induced changes in renin release. In this regard, Laragh et al. [27] found that the action of dietary salt may be linked to its ability to alter $\mathrm{Ca}^{2+}$ metabolism. In "salt sensitive" state, salt intake induces $\mathrm{Ca}^{2+}$ transport on plasma membrane to become more permeable to $\mathrm{Ca}^{2+}$, which results in more $\mathrm{Ca}^{2+}$ accumulation inside the cells leading to a decreased renin production and release. When $\mathrm{Ca}^{2+}$ levels within JG cells are reduced during low salt intake, renin production is increased [24, 27-28]. Although the role of intracellular $\mathrm{Ca}^{2+}$ level in the regulation of renal production and release is well known, the mechanisms mediating $\mathrm{Ca}^{2+}$ changes in response to salt intake remain not fully understood. There is evidence that $\mathrm{Ca}^{2+}$ influx and $\mathrm{IP}_{3}$ receptor-mediated $\mathrm{Ca}^{2+}$ release are involved in renin production and release from the kidney [24]. In a recent study, we reported that increased cADPR level and consequent $\mathrm{Ca}^{2+}$ mobilization contribute to decreased renin production and release in response to stimuli such as increase in $\mathrm{NaCl}$ loading in renin-expressing cell line, As4.1. The present study demonstrated in in vivo animal experiments that the defect of CD38-cADPR mediated signaling pathway enhanced renin release sensitivity to salt intake, indicating that this cADPR-mediated $\mathrm{Ca}^{2+}$ mobilization through RyR may be one of the important molecular mechanisms regulating renin release. There was no difference in PRA between $\mathrm{CD}^{+/ /+}$and CD38\% mice in high salt condition, which indicated that the effect of CD38-cADPR on renin release was counteracted by the increase of calcium influx induced by high salt.

Further performed a series of acute animal experiments to test whether CD38 signaling pathway is involved in renin release in response to renal ischemia induced by isoprenaline infusion. It has been reported that isoprenaline directly activates $\beta$-adrenoceptor on JG cells and stimulates adenylate cyclase to produce cAMP, which causes a cAMP-dependent protein kinase-A activation resulting in renin release [20]. In the present study, isoprenaline was found to increase the PRA by 3 -fold in $\mathrm{CD} 38^{\%}$ mice, which was much higher compared to that observed in $\mathrm{CD}_{3} 8^{+/+}$mice. Given the action of isoprenaline on cAMP, it seems that CD38-mediated signaling and consequent regulation of intracellular $\mathrm{Ca}^{2+}$ levels in JG cells mainly play a permissive role in renin release under such condition. In this regard, some investigators have demonstrated that the inhibitory effect of the $\mathrm{Ca}^{2+}$ pathway is strong enough to overcome any stimulatory effect of the cAMP signaling pathway [25, 29]. It has been proposed that the effect of cAMP and calcium on renin release may be due to the effect of $\mathrm{Ca}^{2+}$ to lower cAMP levels in renin-secreting cells by inhibiting adenylate cyclase activity and by activating cAMP phosphodiesterase activity $[14,26]$. The present study indicated that CD38-cADPR mediated calcium signaling might be involved in fine-tuning renin release induced by cAMP.

Corresponding to increase in renin release, decrease in GFR, RBF, UV and $\mathrm{U}_{\mathrm{Na}} \mathrm{V}$ were more significant in $\mathrm{CD}_{3}{ }^{\%}$ mice than $\mathrm{CD}^{2} 8^{+/+}$mice when they received isoprenaline infusion. This suggests that CD38-cADPR signaling pathway indeed exerts its role in the mediation of renal function via regulation of renin release. Thai et al. [8] reported the functional 
significance of CD38-cADPR signaling pathway in the short-time regulation of renal function and arterial pressure by bolus injection of three vasoconstrictor agents such as angiotensin II, end othelin-1 and norepinephrine. They have demonstrated that CD38 serves as a major ADPribosylcyclase regulating RBF in the renal microcirculation via its action on RyR-mediated $\mathrm{Ca}^{2+}$ mobilization and reactivity in renal microvessel; and that the renal vasculature is less reactive to these vasoconstrictor agents in the absence of $\mathrm{CD} 38$. These studies have suggested that CD38-cADPR signaling in the renal microvasculature may directly mediate or enhance vasomotor responses by increasing intracellular $\mathrm{Ca}^{2+}$ levels in vascular smooth muscle cells. The changes of renal function during 3 hours with the continual infusion isoprenaline have been observed in the present study. Our results indicated that in JG cells, however, CD38cADPR may increase intracellular $\mathrm{Ca}^{2+}$ level to limit the overwhelming release of renin, which may protect the kidney from the detrimental effect of sustained renal vasoconstriction. Indeed, $\mathrm{RBF}$ gradually recovered in $\mathrm{CD} 8^{+/+}$mice, but not in $\mathrm{CD} 38^{-/-}$mice, suggested that high angiotension II concentration existed in the mice with deficiency of CD38 gene. The normal function of CD38-cADPR signaling is important in the maintenance of low vascular tone or resistance due to its action to lower PRA.

In another series of animal experiments, RPP reduction was used to stimulate renin release. It has been reported that reduction of RPP activates both renal baroreceptor and macula densa leading to renin release. The JG cells may be the sensor of changes in RPP and determine renin secretion through the regulation of intracellular $\mathrm{Ca}^{2+}$ level [30-31]. The present study demonstrated that reduction of RPP increased the PRA in CD38 $8^{+/+}$mice, which is consistent with the previous studies in other wild type mouse strains [32]. In CD38 $\%$ mice, the PRA increase in response to reduction of RPP was enhanced by 3 fold. This suggests that the normal function of CD38-cADPR signaling pathway may play a critical role in the inhibition of renin release during RPP deduction. Given the characteristic of CD38 as a type II transmembrane protein with a 20 amino acid hydrophobic transmembrane domain and its mechanosensor action [33-35], it is possible that CD38 can sense the pressure change in the afferent arteries during RPP reduction and thereby induce cADPR production, increasing $\left[\mathrm{Ca}^{2+}\right]_{\mathrm{i}} \mathrm{in} \mathrm{JG}$ cells and thereby resulting in decreased renin release. It means CD38 may act as a "brake" to prevent renin release in some pathology conditions. When CD38 gene expression is deficient, its role on balancing the calcium concentration may be blunted, resulting in decrease of $\left[\mathrm{Ca}^{2+}\right]_{i}$ and consequent increase of renin release.

In summary, we found that the absence of CD38 and consequent lack of cADPR production in the kidney of mice sensitized renin release in response to three major stimuli of renin release including salt intake, RPP reduction and isoprenaline infusion. Corresponding to enhanced renin release, the CD38 deficient mice had more dramatic reduction of RBF and GFR as well as suppression of urinary excretion. The present study for the first time demonstrated that CD38-cADPR signaling is importantly involved in the regulation of renin release from the mouse kidneys, and a functioning CD38 gene is of importance in the regulation of renal function by modulating overwhelming release of renin under certain physiological and pathological conditions.

\section{Grants}

This work was supported by grants from the National Institutes of Health, DK054927, HL075316, and HL57244.

\section{References}

1 Lee HC, Aarhus R: Wide distribution of an enzyme that catalyzes the hydrolysis of cyclic adp-ribose. Biochim Biophys Acta 1993;1164:68-74. 
Xiong/Xia/Yi et al.: Renin Release in CD38 Gene Knockout Mice

2 Lee HC, Aarhus R, Walseth TF: Calcium mobilization by dual receptors during fertilization of sea urchin eggs. Science 1993;261:352-355.

3 Li PL, Lee HC, Nelson MT, Meininger GA, Van Breemen C: Novel $\mathrm{Ca}^{2+}$ signalling mechanisms in vascular myocytes: Symposium overview. Acta Physiol Scand 2003;179:339-352.

4 Itoh M, Ishihara K, Tomizawa H, Tanaka H, Kobune Y, Ishikawa J, Kaisho T, Hirano T: Molecular cloning of murine bst-1 having homology with cd38 and aplysia adp-ribosyl cyclase. Biochem Biophys Res Commun 1994;203:1309-1317.

-5 Kaisho T, Ishikawa J, Oritani K, Inazawa J, Tomizawa H, Muraoka 0, Ochi T, Hirano T: Bst-1, a surface molecule of bone marrow stromal cell lines that facilitates pre-b-cell growth. Proc Natl Acad Sci U S A 1994;91:5325-5329.

6 Zhang AY, Yi F, Teggatz EG, Zou AP, Li PL: Enhanced production and action of cyclic adp-ribose during oxidative stress in small bovine coronary arterial smooth muscle. Microvasc Res 2004;67:159-167.

7 Fowler MR, Cooper GJ, Hunter M: Regulation and identity of intracellular calcium stores involved in membrane cross talk in the early distal tubule of the frog kidney. Am J Physiol Renal Physiol 2004;286:F1219-1225.

8 Thai TL, Arendshorst WJ: Adp-ribosyl cyclase and ryanodine receptors mediate endothelin eta and etb receptor-induced renal vasoconstriction in vivo. Am J Physiol Renal Physiol 2008;295:F360-368.

-9 Thai TL, Arendshorst WJ: Mice lacking the adp ribosyl cyclase cd38 exhibit attenuated renal vasoconstriction to angiotensin ii, endothelin-1, and norepinephrine. Am J Physiol Renal Physiol 2009;297:F169-176.

10 Thai TL, Fellner SK, Arendshorst WJ: Adp-ribosyl cyclase and ryanodine receptor activity contribute to basal renal vasomotor tone and agonist-induced renal vasoconstriction in vivo. Am J Physiol Renal Physiol 2007;293:F1107-1114.

11 Yusufi AN, Cheng J, Thompson MA, Dousa TP, Warner GM, Walker HJ, Grande JP: Cadp-ribose/ryanodine channel/ $\mathrm{Ca}^{2+}$-release signal transduction pathway in mesangial cells. Am J Physiol Renal Physiol 2001;281:F91-F102.

12 Schmieder RE, Hilgers KF, Schlaich MP, Schmidt BM: Renin-angiotensin system and cardiovascular risk. Lancet 2007;369:1208-1219.

13 Freeburg PB, Abrahamson DR: Dissecting the jga: New functions for jg cells? Am J Physiol Regul Integr Comp Physiol 2004;286:R449-450.

14 Kurtz A: Control of renin synthesis and secretion. Am J Hypertens 2012;25:839-847.

15 Schweda F, Kurtz A: Cellular mechanism of renin release. Acta Physiol Scand 2004;181:383-390.

16 Hayashi K, Wakino S, Sugano N, Ozawa Y, Homma K, Saruta T: $\mathrm{Ca}^{2+}$ channel subtypes and pharmacology in the kidney. Circ Res 2007;100:342-353.

17 Yi F, Zhang AY, Li N, Zhang F, Xia M, Li PL: Role of cyclic adp-ribose-Ca ${ }^{2+}$ signaling in mediating renin production and release in as4.1 cells. Cell Physiol Biochem 2007;19:293-302.

18 Yi F, Zhang AY, Li N, Muh RW, Fillet M, Renert AF, Li PL: Inhibition of ceramide-redox signaling pathway blocks glomerular injury in hyperhomocysteinemic rats. Kidney Int 2006;70:88-96.

19 Menard J, Catt KJ: Measurement of renin activity, concentration and substrate in rat plasma by radioimmunoassay of angiotensin i. Endocrinology 1972;90:422-430.

20 Moosavi SM, Johns EJ: The effect of isoprenaline infusion on renal renin and angiotensinogen gene expression in the anaesthetised rat. Exp Physiol 2003;88:221-227.

21 Moosavi SM, Johns EJ: Effect of renal perfusion pressure on renal function, renin release and renin and angiotensinogen gene expression in rats. J Physiol 1999;520:261-269.

22 Li N, Teggatz EG, Li PL, Allaire R, Zou AP: Formation and actions of cyclic adp-ribose in renal microvessels. Microvasc Res 2000;60:149-159.

23 Wagner C, Kurtz A: Regulation of renal renin release. Curr Opin Nephrol Hypertens 1998;7:437-441.

24 Beierwaltes WH: The role of calcium in the regulation of renin secretion. Am J Physiol Renal Physiol 2010;298:F1-F11.

25 Grunberger C, Obermayer B, Klar J, Kurtz A, Schweda F: The calcium paradoxon of renin release: Calcium suppresses renin exocytosis by inhibition of calcium-dependent adenylate cyclases ac5 and ac6. Circ Res 2006;99:1197-1206. 


\begin{tabular}{|c|c|c|}
\hline Cellular Physiology & Cell Physiol Biochem 2013;31:44-55 & \\
\hline and Biochemistry & 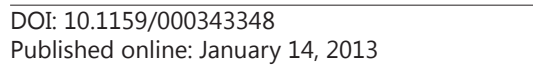 & $\begin{array}{l}\text { O) } 2013 \text { S. Karger AG, Basel } \\
\text { www.karger.com/cpb }\end{array}$ \\
\hline
\end{tabular}

26 Ortiz-Capisano MC, Liao TD, Ortiz PA, Beierwaltes WH: Calcium-dependent phosphodiesterase 1c inhibits renin release from isolated juxtaglomerular cells. Am J Physiol Regul Integr Comp Physiol 2009;297:R1469-1476.

-27 Laragh JH, Sealey JE: Abnormal sodium metabolism and plasma renin activity (renal renin secretion) and the vasoconstriction volume hypothesis: Implications for pathogenesis and treatment of hypertension and its vascular consequences (heart attack, stroke). Clin Chem 1991;37:1820-1827.

-28 Ginesi LM, Noble AR: Secretion control for active and inactive renin: Effect of ouabain on release from rabbit kidney cortex slices. J Physiol 1986;379:17-26.

29 Ortiz-Capisano MC, Ortiz PA, Harding P, Garvin JL, Beierwaltes WH: Adenylyl cyclase isoform v mediates renin release from juxtaglomerular cells. Hypertension 2007;49:618-624.

30 Hackenthal E, Paul M, Ganten D, Taugner R: Morphology, physiology, and molecular biology of renin secretion. Physiol Rev 1990;70:1067-1116.

-31 King JA, Lush DJ, Fray JC: Regulation of renin processing and secretion: Chemiosmotic control and novel secretory pathway. Am J Physiol 1993;265:C305-320.

-32 Fujino T, Nakagawa N, Yuhki K, Hara A, Yamada T, Takayama K, Kuriyama S, Hosoki Y, Takahata O, Taniguchi T, Fukuzawa J, Hasebe N, Kikuchi K, Narumiya S, Ushikubi F: Decreased susceptibility to renovascular hypertension in mice lacking the prostaglandin i2 receptor ip. J Clin Invest 2004;114:805-812.

-33 Umesh A, Thompson MA, Chini EN, Yip KP, Sham JS: Integrin ligands mobilize $\mathrm{Ca}^{2+}$ from ryanodine receptor-gated stores and lysosome-related acidic organelles in pulmonary arterial smooth muscle cells. J Biol Chem 2006;281:34312-34323.

-34 Yeung PK, Lam CM, Ma ZY, Wong YH, Wong JT: Involvement of calcium mobilization from caffeine-sensitive stores in mechanically induced cell cycle arrest in the dinoflagellate crypthecodinium cohnii. Cell Calcium 2006;39:259-274.

-35 Zhang AY, Li PL: Vascular physiology of a $\mathrm{Ca}^{2+}$ mobilizing second messenger - cyclic adp-ribose. J Cell Mol Med 2006;10:407-422. 